Review Article

Saida Laalioui*, Kawtar Belrhiti Alaoui, Houda Ait Dads, Kassem El Assali, Badr Ikken, and Abdelkader Outzourhit

\title{
Progress in perovskite based solar cells: scientific and engineering state of the art
}

https://doi.org/10.1515/rams-2020-0017

Received Feb 05, 2019; accepted Oct 25, 2019

\begin{abstract}
Perovskite solar cells (PSCs) are one of the most promising photovoltaic technologies undergoing rapid developments. PSC efficiency has reached $25.2 \%$ in only seven years, which is close to the record efficiency of silicon solar cells. In addition, the use of PSCs in tandem solar cells either in the 4-terminal or monolithic configuration, can lead to a significant increase conversion efficiency. However, the stability and the scalability are the main issues that still hinder the commercialization of the perovskite technology.

The present review focusses on the recent development in perovskite solar cells materials, cell architectures and fabrication methods and their effect on the conversion efficiency and stability of the devices. In addition, solutions proposed to overcome the main challenges and to make tandem solar cells are discussed.
\end{abstract}

Keywords: Hybrid perovskite; Stability; Thin films; High efficiency solar cells; Perovskite solar cells; Perovskite tandem solar cells; Silicon tandem solar cells; CIGS tandem

*Corresponding Author: Saida Laalioui: Laboratory of Nanomaterials for Energy and Environment (LNEE), Faculty of Sciences Semlalia, Cadi Ayyad University, PO Box: 2390, Marrakech 40000, Morocco; Research Institute for Solar Energy and New Energies (IRESEN),16, street Amir Sidi Mohamed souissi - Rabat 10000, Morocco; Email: laalioui@iresen.org; saida2laalioui@gmail.com; Fax: +212 (0) 537688852

Kawtar Belrhiti Alaoui: Laboratory of Nanomaterials for Energy and Environment (LNEE), Faculty of Sciences Semlalia, Cadi Ayyad University, PO Box: 2390, Marrakech 40000, Morocco; Research Institute for Solar Energy and New Energies (IRESEN),16, street Amir Sidi Mohamed souissi - Rabat 10000, Morocco

Houda Ait Dads, Kassem El Assali, Abdelkader Outzourhit: Laboratory of Nanomaterials for Energy and Environment (LNEE), Faculty of Sciences Semlalia, Cadi Ayyad University, PO Box: 2390, Marrakech 40000, Morocco

Badr Ikken: Research Institute for Solar Energy and New Energies (IRESEN),16, street Amir Sidi Mohamed souissi - Rabat 10000, Morocco solar cells; Solar cells configurations, Perovskite solar cells materials

\section{Introduction}

Perovskites refer to a group of materials with the formula of $\mathrm{ABX}_{3}$ that crystallize in the $\mathrm{CaTiO}_{3}$-type perovskite structure [1]. In hybrid perovskites absorbers used in solar cells, A is an organic cation of formula $\mathrm{R}^{-\mathrm{NH}_{3}^{+}}$, B is a divalent metal of the group 14 of the periodic table $\left(\mathrm{Pb}^{2+}, \mathrm{Sn}^{2+}, \mathrm{Ge}^{2+} \ldots\right)$, and $\mathrm{X}$ is a halide ion $\left(\mathrm{I}^{-}, \mathrm{Cl}^{-}\right.$, $\left.\mathrm{Br}^{-}\right)$. As shown in Figure 1, their structure consists of a $3 \mathrm{D}$ stack of $\mathrm{BX}_{6}$ octahedra that touch at the vertices, with the $\mathrm{A}^{+}$cations occupying the interstitial sites of the three-dimensional inorganic structure [1]. Methylammonium $\mathrm{CH}_{3} \mathrm{NH}_{3}^{+}$(MA), Formamidinium $\mathrm{HC}\left(\mathrm{NH}_{2}\right)^{2+}(\mathrm{FA})$ and Cesium $\left(\mathrm{Cs}^{+}\right)$are the most used cations in the perovskite absorbers. Larger cations, like ethyl-ammonium (EA), can also be used. However, the perovskite structure changes dimensionality from three-(3D) to two-dimensions (2D) with a significant change in the optical gap of the material. Moreover, the combination between the different elements $\mathrm{A}, \mathrm{B}$ and $\mathrm{X}$ constituting the hybrid perovskite leads to various properties and cell performances [2-7].

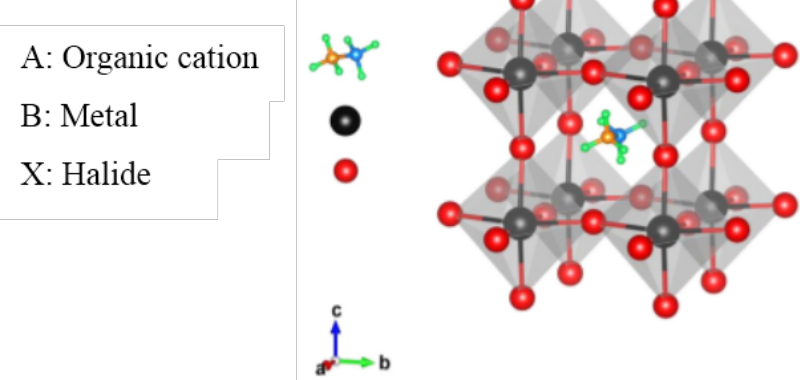

Figure 1: Crystalline structure of the hybrid perovskite [4]

This class of hybrid materials has a wide range of properties and characteristics that are attractive for solar cells, 
namely: 1) a direct band-gap that can easily be tuned between 1.30 and $2.5 \mathrm{eV}[2,8,9]$ by an appropriate selection of the mixed cations and halides $[2,10] ; 2)$ a low exciton binding energy $(<10 \mathrm{meV}) ; 3)$ a large absorption coefficient on the order of $1.5 \times 10^{4} \mathrm{~cm}^{-1}$ at $550 \mathrm{~nm} \mathrm{[2];} \mathrm{4)} \mathrm{a}$ high carrier lifetime compared with silicon [2]; 5) an ambipolar conductivity and a good mobility of the carriers compared to the organic materials, namely: $7.5 \mathrm{~cm}^{2} / \mathrm{Vs}$ for holes and $12.5 \mathrm{~cm}^{2} / \mathrm{Vs}$ for electrons [2]. In addition, the hybrid perovskites offer absorption of wavelengths up to 800 $\mathrm{nm}[2,9,10]$, a good separation of charge carriers, which explains the high open-circuit voltages $\left(\mathrm{V}_{o c}\right)$ of PSC, which can reach up to $1.02 \mathrm{~V}[2,10]$. Indeed, perovskites present high diffusion lengths for holes and electrons, reaching $100 \mathrm{~nm}$ for $\mathrm{MAPbI}_{3}$ and exceeding $1 \mu \mathrm{m}$ in $\mathrm{MAPbI}_{3-x} \mathrm{Cl}_{x}$ $[1,2]$. This feature coupled with good light absorption leads to high short-circuit current density $\left(\mathbf{J}_{\text {sc }}\right.$ ) values up to 23 $\mathrm{mA} / \mathrm{cm}^{2}$ [2].

Moreover, the perovskite solar cell can be elaborated with simple and low temperature process [11], which enables to lower the cost of the devices compared with silicon thin film technologies.

Indeed, wet chemistry routes such as spin-coating, spray-deposition, dip-coating, printing techniques as well as other coating/printing techniques are widely used techniques to develop hybrid perovskites [12]. However, vapor deposition techniques lead to flat and uniform films and offer better thin film qualities than spin-coating [8]. Furthermore, combining wet chemistry and vapor deposition techniques results in higher grain size and complete surface coverage [1].

Perovskite solar cell architectures evolved from mesoporous type to planar junctions. This later architecture is considered to be the most interesting since it is simple and offers low cost for mass production and can yield high performances [13]. In this configuration, the Perovskite absorber is sandwiched between an electron transport layer (ETL) and a hole transport layer (HTL) [8]. However, the nature of the layers constituting the PSC affects the performances of the devices [2, 4, 5, 14-19].

Despite all these advantages, moisture, UV-light and temperature can greatly affect the stability of the PSC cells and lead to their degradation [20]. Nevertheless, an adequate selection of the elements of the hybrid perovskite as well as of the carrier selective layers could improve the stability of the devices [5, 21]. Furthermore, Uv-filters, and encapsulation are considered as efficient way to protect the cells against external factors [4, 22].

Perovskite cells have also been recently used in tandem structures due to the tunability of the band gap of these materials. Indeed, the large band-gap of some perovskites makes them very attractive for a top cell in tandem structures, with efficiencies of $20.3 \%$ for Perovskite/perovskite [23], 21.0\% CIGS/perovskite [24], $23.6 \%$ silicon-hetero-junction/perovskite [25] structures. This later, is demonstrated as one of the best ways to improve the matured and stagnated photovoltaic technologies at reasonable costs [26].

The present review focusses on the recent development in perovskite solar cells materials, cell architectures and fabrication methods and their effect on the conversion efficiency and stability of the devices. In addition, solutions proposed to overcome the main challenges and to make tandem solar cells are discussed. The latest developments in the field of perovskite solar cells either in simple junction or in tandem configurations are also reviewed. The materials used in different layer constituting the device and their effect on the stability and performance of the solar cells are discussed. Furthermore, the different fabrication techniques to deposit the perovskite thin film are presented and their effect on the proprieties of the thin films are discussed. In addition, the mechanism of the instability of the perovskite solar cell is presented and the possible solution to overcome this issue are proposed. Furthermore, the tandem solar cells based on the perovskite sub cells combined with different technologies, especially CIGS, Perovskite and silicon heterojunction solar cells are also reviewed.

\section{Fabrication of perovskite films}

The fabrication of perovskite absorbers doesn't require heavy equipment and can be carried out at relatively lower temperatures compared to silicon [11]. This, in addition to high efficiency, can lead to a significant lowering of the cost of this technology. Indeed, silicon wafers issued from high purity ingots are essential component in the silicon solar cell and they constitute above $70 \%$ of the cost of the whole device [27]. Furthermore, poly- or microcrystalline silicon thin-film solar cells preparation requires deposition temperatures of $1000^{\circ} \mathrm{C}$ by Chemical Vapor Deposition [28], or 200 and $450^{\circ} \mathrm{C}$ with a pressure between 0.1 and 1 mbar by Plasma Enhanced Chemical Vapor Deposition (PECVD) [29], which is considered as a low temperature process. In contrast, perovskite thin films are prepared either by solvent-process deposition, vapor deposition or combined processes, that require most of the times a spin coater and an evaporator, which are considered as simple equipments, followed by an annealing step in the temperature range between 100 and $190^{\circ} \mathrm{C}[30,31]$. 
In fact, several methods have been used to develop hybrid perovskite layers. Wet chemistry routes are widely used in this regard. The precursors of the perovskite are dissolved in solvents, and deposited via spin-coating, spray-deposition, dip-coating, printing techniques as well as other coating/printing techniques [12].

The spin coating technique (Figure 2) is the most used method because it is simple, fast and low cost $[1,2,12]$. Indeed, the perovskite thin film deposition can be realized in few seconds, by dripping a dozen $\mu \mathrm{l}$ of the precursors solution on a substrate fixed on the spin-coater. Furthermore, the precursor material and the spin-coater are lowcost compared to those used for other technologies. However, high performances can be obtained compared to the famous silicon solar cells. As a result, the perovskite solar cell cost above 10 to 20 cents per Watt, while for other the technologies the cost is 80 cents/Watt, compared to \$77/Watt in 1977 [32].

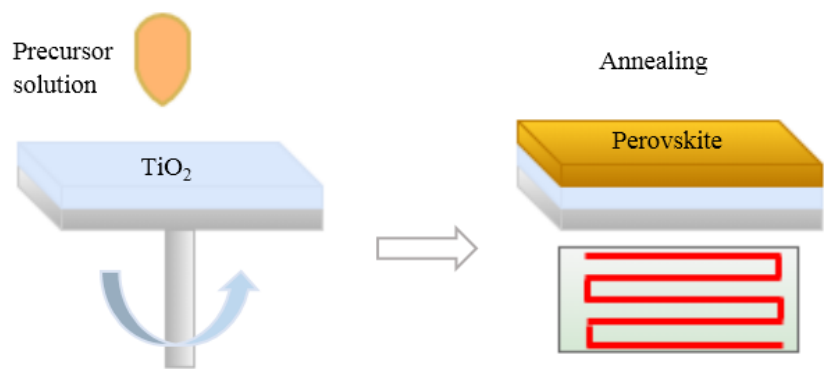

Figure 2: One step spin-coating method

The deposition can be performed either in a single or in two steps followed by a heat treatment. In the one-step method, lead (II) halide $\left(\mathrm{PbI}_{2}\right)$ and methyl-ammonium halide (MAI) are dissolved to form the precursor solution, which is then deposited on a substrate coated by titanium dioxide $\left(\mathrm{TiO}_{2}\right)$ by spin-coating. This technique is considered to be better in terms of step and time minimization, but it does not offer the control of either the growth kinetics of the crystals or the morphology of the coating [8]. The two-step technique consists of depositing a solution containing $\mathrm{PbI}_{2}$ first, followed by the deposition of the other solution containing MAI. The performance of perovskites deposited by this process is higher as a result of the morphology and microstructure of the resulting films $[8,10]$.

Other derivative techniques have also been used such as the anti-solvent method, which consists of depositing the perovskite by spin-coating, and, after a specific time, the anti-solvent is rapidly added to the substrate, to promote rapid nucleation and growth of perovskite. This tech- nique was proposed to yield flat and uniform perovskite films with well-developed grains [8].

In the hot-casting technique, the precursor solution is heated to a temperature of $70^{\circ} \mathrm{C}$, and is then deposited by spin coating on a glass substrate heated to a temperature close to or greater than the boiling point of the solvent [31]. This technique favors the formation of large perovskite grains with a size of about 1 to $2 \mathrm{~mm}$, which is significantly larger than the 1 to 2 microns obtained by the other methods using the post-deposition annealing. In addition, the films prepared by this method are exempt of pinholes and cover the entire surface of the substrate [31].

Despite the advantages offered by the spin-coating, this technique wastes large amounts of material and is incompatible with the roll-to-roll processing and cannot be scaled for large area. However, spray deposition, ink-jet printing, slot-die coating, blade-coating and screen printing, can overcome these drawbacks [12].

Vapor deposition method has also been used for the fabrication of thin layers of hybrid perovskites [1], either in one or two steps. This technique guarantees flat and uniform films and offers better quality than spin-coating [8], since it avoids the formation of pinholes resulting from solvent evaporation $[1,8]$.

The two-step (sequential) vapor deposition (Figure 3) allows the control of the deposition rate of MAI, which is not feasible in the co-deposition. In addition, the problems resulting from the use of solvents such as the slow crystallization of the perovskite and the pinhole formation within the perovskite film are avoided $[1,8]$. Moreover, the vapordeposited $\mathrm{MAPbI}_{3-x} \mathrm{Cl}_{x}$ perovskite offer a high carrier mobility of $33 \mathrm{~cm}^{2} \mathrm{~V}^{-1} \mathrm{~s}^{-1}$ [33], which is almost the triple of that measured $\left(11.6 \mathrm{~cm}^{2} \mathrm{~V}^{-1} \mathrm{~s}^{-1}\right)$ for the same films deposited by the solution process [3].

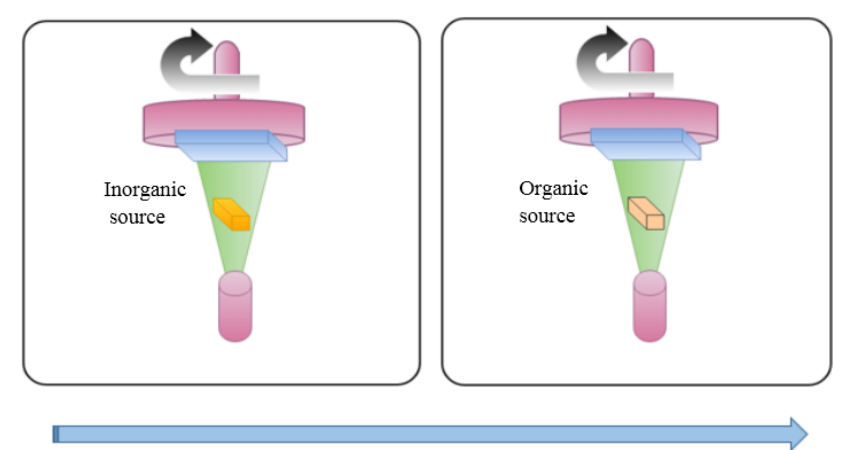

Figure 3: The sequential dual-source vapor deposition technique

Another method that was used is vapor-assisted solution deposition (VASP) where a thin layer of the first precur- 

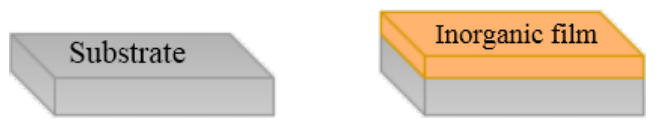

Figure 4: The vapor assisted solution process (VASP)

sor is deposited on a substrate by a solution method. This film is then exposed to the vapor of the second precursor (Figure 4) [8]. The perovskite film obtained by this technique has a complete surface coverage, a uniform grain structure with particle size up to micrometers, and $100 \%$ precursor transformation [1]. The vapor assisted solution process (VASP) is a simple, controllable and versatile approach to obtain high quality perovskite layers and results in high-performance photovoltaic devices.

To improve the quality of the perovskite films, several solutions have been proposed. Indeed, a simple chemical approach was developed to improve the quality of perovskite films by adding an appropriate amount of acetic acid [34]. The introduction of acetate ions allows to obtain a homogeneous and continuous perovskite film, without pinholes and composed of grains with a high degree of crystallinity. Furthermore, the solar cells based on these films have shown an efficiency of up to $14.17 \%$ [34].

Other solutions were proposed to improve the quality of one-step spin-coating deposition by adding $\mathrm{CH}_{3} \mathrm{NH}_{3} \mathrm{Cl}$ to the precursor solution [35]. In addition, a 1: 3 ratio of $\mathrm{PbI}_{2}$ : MAI resulted in films with good performances, including a continuous film and cells with an efficiency of up to $19 \%$ [2]. furthermore, the addition of $1 \%$ of 1,8 diiodooctane (DIO) to the precursor solution, makes it possible to obtain a perovskite film of good quality as well as cells with improved performances [2].

Lead $(\mathrm{Pb})$ is an essential component in the majority of the hybrid perovskite absorbers, which is harmful health and to the environment. Adequate handling of this issue is required before PCS can be widely used. Fortunately, the amount of lead used in the perovskite solar cell is very small compared to the widely used lead-acid batteries. Moreover, $\mathrm{Pb}$ can be substituted partially or totally by less toxic elements such Sn, Ge. However, the efficiency and the stability of the resulted perovskite remain to be optimized [1, 4]. Furthermore, adequate encapsulation of the perovskite solar cell can improve their resistance to severe external conditions [36]. Adequate recycling of the $\mathrm{Pb}$,
Organic vapor
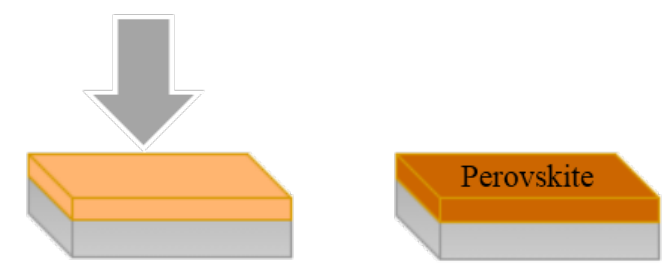

even from lead-acid batteries, is another alternative to reduce the environmental impact of the use of this element. Indeed, high purity $\mathrm{PbI}_{2}$ precursor can be produced from these wastes and used again in fabrication of the PSC [36]. Moreover, A. Binek et al. reported a suitable protocol to recycle used perovskite solar cells, in which each layer is recuperated individually, and can be reused to elaborate a new PCS with a similar performances to the previous device [37]. This protocol allows also the recovery of the expensive Glass/FTO substrate; which may also contribute to the reduction of the cost of the perovskite solar cells

\section{Progress in perovskite solar cell}

\subsection{Evolution of the structure of perovskite solar cells}

Perovskites were first integrated in dye-sensitized solar cells (DSSCs) to replace the conventional dyes, thus resulting in perovskite-sensitized solar cell (PSSC) [38]. They demonstrated a higher capacity to convert photons into electricity compared to the ruthenium N719 dye used in DSSCs [39]. However, the stability of this kind of cells was unfortunately affected by the use of liquid electrolytes. Furthermore, the corrosive nature of the redox couple can also cause damages to the device [40]. Moreover, leakage and solvent evaporation may occur, which hinders the progress of this technology.

In order to reduce losses in the DSSCs, the mesosuperstructured cell (MSSC) was developed, where an extremely thin layer of the perovskite absorber is coated on the internal surface of mesoporous $\mathrm{TiO}_{2}$ or $\mathrm{Al}_{2} \mathrm{O}_{3}$ films [41]. In this structure, the carrier transport distance is decreased, thus enhancing charge collection [40]. Further, an open-circuit voltage $1.1 \mathrm{eV}$ was achieved for a perovskite with a band-gap of $1.55 \mathrm{eV}$. However, series and shunt resis- 
tances of the MSSC, are still an obstacle to the performance of the device, and remain to be optimized [41].

Subsequently, the mesoporous structure was proposed, in which the perovskite covers the surface of the $\mathrm{TiO}_{2}$ nanoparticles by filling the pores of the mesoporous film [42]. In this structure, the contact area between the Perovskite and the ETL is increased, which makes the collection of electrons easier [43]. Furthermore, mesoscopic perovskite solar cells present a lower density of traps and less hysteresis compared to the planar architecture [43, 44]. Moreover, this kind of solar cell exhibit better stability and performance than the planar solar cells [45, 46]. However, the mesoporous oxide and the blocking layer require a sintering step above $500^{\circ} \mathrm{C}$ [13], which may increase the fabrication cost of these solar cells.

Finally, in the planar heterojunction architecture the perovskite layer is sandwiched between an n-type and p-type layers [8]. Indeed, unlike the mesoporous structure, this structure doesn't require any mesoporous $\mathrm{TiO}_{2}$ while the device can reach efficiencies similar to those of the mesoporous structure with lower processing temperatures [47, 48]. However, this structure exhibits the hysteresis phenomenon [49], which can be fortunately, reduced by treating the surface defects of the perovskite thin films [50]. Furthermore, this later architecture is simple and offers low cost for mass production and can yield high performances [13].

The perovskite planar solar cell (Figure 5) is composed of glass substrate covered with a transparent conducting oxide (TCO), an electron transport layer made of $n$-type semiconductor, the hybrid Perovskite absorber film, a hole transport layer consisting of p-type semiconductor and finally a metallic top contact [2]. The planar perovskite solar cells can have two configurations p-i-n or n-i-p [1, 2]. How-

a)

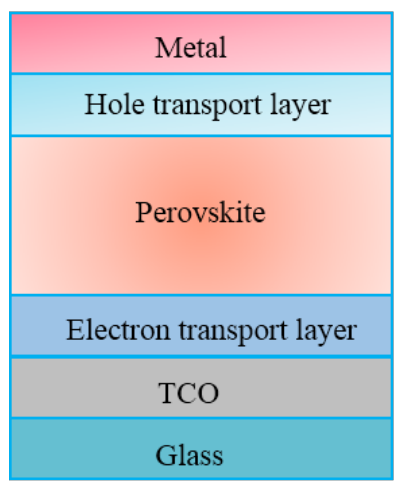

Figure 5: Perovskite solar cell structures a), b) n-i-p and p-i-n configuration ever, the most efficient cells are those with a p-i-n configuration [2]. Structures without either electron or hole transport layers were also developed [2], since the perovskite materials are ambipolar, as they allow the conduction of both electrons and holes [1].

Besides the layers constituting the standard PSCs, an antireflective coating can be added to reduce the reflection losses [26, 51, 52]. Several materials such as magnesium fluoride [51], Lithium fluoride (LIF) [52], and others were used for this purpose. With such treatments, the efficiency of the solar cell can be enhanced by $3 \%$ [26].

\subsection{Evolution of the perovskite solar cells materials}

\section{Perovskite Absorber}

The perovskite absorber, the principal layer in the PSCs, is photo-active in the visible region of the solar spectrum. The combination between the different elements A, B and $\mathrm{X}$ constituting the perovskite leads to various properties and cell performances.

Tin-based perovskites are very unstable, due to the instability of the $\mathrm{Sn}^{2+}$ ions which are easily oxidized to $\mathrm{Sn}^{4+}$ [4]. In addition, perovskites containing tin such as $\mathrm{MASnX}_{3}$ have optical band gaps between 1.2 and $1.4 \mathrm{eV}$ and result in cell efficiencies not exceeding $6 \%$, which is lower than those of cells based on $\mathrm{MAPbX}_{3}$. The band gaps of the latter perovskites are between 1.6 and $1.8 \mathrm{eV}$ and can result in efficiencies of up to $19.7 \%[2,8]$. This makes leadbased perovskites better suited for the solar cells [1].

The methylammonium lead iodide hybrid perovskite has an optical band gap between 1.51 and $1.55 \mathrm{eV}$. When the methylammonium cation (MA) is replaced by the formamidinium (FA), the optical band gap decreases to values between 1.43 and $1.48 \mathrm{eV}$ [2] and the best cell efficiency reached in this class of perovskites is $20.2 \%$ [5]. However, the perovskites containing cesium (Cs) as a cation and bromine $(\mathrm{Br})$ as a halide $\left(\mathrm{CsPBr}_{3}\right)$, have a wide bandgap of $2.25 \mathrm{eV}$, and lead to an efficiency of $5.95 \%$. This is why this combination of elements is not ideal for photovoltaic cells [6]. On the other hand, cesium lead iodide perovskite $\left(\mathrm{CsPbI}_{3}\right)$, has a band gap of $1.73 \mathrm{eV}$ and properties suitable for photovoltaic cells [7]. However, brominebased perovskites, are known for their high band-gap, improved performance as well as stability of the perovskite solar cells [2].

The combination of two halides offered better performances. Indeed, cells based on perovskites mixed halides (I, Cl) demonstrated an efficiency of $12.7 \%$, and an im- 
Table 1: Band gaps and efficiencies of solar cells based on the perovskite absorbers

\begin{tabular}{|c|c|c|c|}
\hline Perovskite & Gap & Efficiency & Reference \\
\hline $\mathrm{MASnX}_{3}$ & $1,2-1,4 \mathrm{eV}$ & $6 \%$ & [2] \\
\hline $\mathrm{MAPbX}_{3}$ & $1,6-1,8 \mathrm{eV}$ & $19.7 \%$ & [8] \\
\hline $\mathrm{MAPbl}_{3}$ & $1,51-1,55 \mathrm{eV}$ & $19.7 \%$ & {$[8]$} \\
\hline $\mathrm{FAPbl}_{3}$ & $1,43-1,48 \mathrm{eV}$ & $20.2 \%$ & {$[5]$} \\
\hline $\mathrm{MAPblxBr}_{3-\mathrm{x}}$ & $1,48-2,23 \mathrm{eV}$ & $14,9 \%$ & {$[2]$} \\
\hline MAPblxCl $3-x$ & - & $12,7 \%$ & [3] \\
\hline $\mathrm{CsPbI}_{3}$ & $1,73 \mathrm{eV}$ & - & [7] \\
\hline $\mathrm{CsPbBr}_{3}$ & $2,25 \mathrm{eV}$ & $5,95 \%$ & [6] \\
\hline $\mathrm{Cs}_{\mathrm{X}}(\mathrm{MA})_{1-\mathrm{x}} \mathrm{Pbl}_{3}$ & - & $7,68 \%$ & {$[2]$} \\
\hline$C s_{X}(F A)_{1-X} P_{3}$ & - & $16,5 \%$ & [7] \\
\hline$(\mathrm{MA})_{\mathrm{X}}(\mathrm{FA})_{1-\mathrm{x}} \mathrm{Pbl}_{3}$ & - & $14,9 \%$ & {$[2]$} \\
\hline $\mathrm{MA}_{0.17} \mathrm{FA}_{0.83} \mathrm{~Pb}\left(\mathrm{I}_{0.83} \mathrm{Br}_{0.17}\right)_{3}$ & - & $20,2 \%$ & [7] \\
\hline $\mathrm{Cs}_{\mathrm{X}}\left(\mathrm{MA}_{0.17} \mathrm{FA}_{0.83}\right)_{(100-\mathrm{x})} \mathrm{Pb}\left(\mathrm{I}_{0.83} \mathrm{Br}_{0.17}\right)_{3}$ & - & $21,1 \%$ & [7] \\
\hline
\end{tabular}

proved stability compared to iodides [3]. Furthermore, methylamunium lead bromide-iodide $\mathrm{MAPbI}_{x} \mathrm{Br}_{3-x}$ perovskites have a tunable band gap between 1.48 and 2.23 $\mathrm{eV}$ and resulted in a maximum efficiency of $14.9 \%$ [2].

Moreover, the best single junction perovskite solar cells were made of mixed organic cations (methylammonium (MA) and formamidinium (FA)) and mixed halides (Br and $\mathrm{I})$. Indeed, the perovskite absorber $(\mathrm{MA})_{x}(\mathrm{FA})_{1-x} \mathrm{PbI}_{3}$ yielded an efficiency of up to $14.9 \%$ [2], while the $\mathrm{MA}_{0.17} \mathrm{FA}_{0.83} \mathrm{~Pb}\left(\mathrm{I}_{0.83} \mathrm{Br}_{0.17}\right)_{3}$ perovskite lead to a higher efficiency of up to $20.2 \%$ [7]. However, $\mathrm{Cs}_{x}(\mathrm{MA})_{1-x} \mathrm{PbI}_{3}$ resulted in an efficiency on the order of $7.68 \%$ [2], but the mixture of Cs and FA cations allowed to increase the efficiency to $16.5 \%$ [7].

One of the interesting approaches is to combine cesium Cs with the two organic cations (MA and FA) to get a triple cation configuration (Cs / MA / FA). This approach allowed to reach an efficiency up to $21.1 \%$ using the absorber $\mathrm{Cs}_{x}\left(\mathrm{MA}_{0.17} \mathrm{FA}_{0.83}\right)_{(1-x)} \mathrm{Pb}\left(\mathrm{I}_{0.83} \mathrm{Br}_{0.17}\right)_{3}$ [7]. Furthermore, this configuration offers a reproducible perovskite films with a good thermal stability.

However, when MA is replaced by a larger cation such as Ethylamonium EA, the structure of the perovskite changes completely, moving from a three-dimensional structure to a two-dimensional one that is more resistant to solar radiation and humidity [2].

From this review, it can be seen that there is a close relationship between the performances of the perovskite solar cells and the absorber materials. The efficiencies of the PSCs using the previous absorbers are summarized in Table 1.

\section{Electron transport layer (ETL)}

The perovskite absorber is often deposited on an electron transport layer (ETL) to facilitate efficient electron collection and transport from the perovskite absorber. To guarantee high efficiency, material used us ETL must have a good electron mobility, wide band-gap to allow fast electron transport and to maximize light absorption by the absorber layer respectively [46].

Several materials were used as ETL, specially the metal oxides such as $\mathrm{TiO}_{2}, \mathrm{ZnO}, \mathrm{SnO}_{2}, \mathrm{SiO}_{2}, \mathrm{ZrO}_{2}$. In addition, organic material such as PEHT, [6,6]-Phenyl $\mathrm{C}_{61} \mathrm{Bu}$ tyric acid Methyl ester (PCBM), or PEHT: PBCM composites [15] also showed good performances.

Titanium dioxide $\mathrm{TiO}_{2}$ has been widely used as ETL in perovskite solar cells. However, this layer is sensitive to ultraviolet radiation, which induces a degradation of the absorber and consequently affects the efficiency and the lifetime of the whole cell with a stability of 500 hours [5].

Zinc oxide $\mathrm{ZnO}$ and tin dioxide $\mathrm{SnO}_{2}$ lead to similar or improved performance compared to $\mathrm{TiO}_{2}$ [16]. Indeed, zinc oxide $\mathrm{ZnO}$, which is simple to synthesize and has excellent electrical properties, offered solar cells with $15 \%$ efficiency. However, the thermal stability of the perovskite deposited on this oxide needs to be improved [16, 17]. Furthermore, Al-doped $\mathrm{ZnO}$ (AZO) was also used as an electron transport layer, as well as transparent conductive oxide (TCO), thus allowing a simplified structure of solar cells in the form glass / AZO / perovskite / Spiro-OMeTAD / Au [16]. This type of structure offered an efficiency of $12.6 \%$ and a good thermal stability compared to that of cells based on intrinsic ZnO. 
In addition, perovskite deposited on $\mathrm{SnO}_{2}$ showed a higher stability of more than 700 hours [4]. Furthermore, studies have shown that alumina $\left(\mathrm{Al}_{2} \mathrm{O}_{3}\right)$ can replace the $\mathrm{TiO}_{2}$, giving an efficiency of $10.9 \%$ [41]. However, the injection of electrons from $\mathrm{MAPbI}_{3}$ to $\mathrm{Al}_{2} \mathrm{O}_{3}$ is unfavorable since the conduction band position of the $\mathrm{Al}_{2} \mathrm{O}_{3}$ is higher than that of $\mathrm{MAPbI}_{3}[8]$.

\section{Hole transport layer (HTL)}

The use of hole transporting materials makes it possible to improve the performance of the cells. In fact, PSC without a hole transporting layer exhibited an efficiency of $7.3 \%$, with gold $(\mathrm{Au})$ as a top contact [2]. When the Spiro-OMeTAD (2,2'7,7'-tetrakis (N,N-di-pmethoxyphenylamine) -9,9'-spirobiflurene) is added to the cell, a higher efficiency on the order of $9.7 \%$ were reached [2]. The Spiro-OMeTAD is the most commonly used HTL in perovskite solar cells as it results in an improved efficiency [18], and a better solar cell stability thanks to its hydrophobic nature [18].

Copper iodide CuI was also used as a hole transporting material since it is cheaper, and results in a better fill factor (FF) and a more stable current density than Spiro-OMeTAD. However, it yields a lower open circuit voltage $\left(\mathrm{V}_{o c}\right)$, which limits the efficiency of the cell to only $8.3 \%$ [19].

A well-known conjugated polymer, poly (3,4ethylenedioxythiphene) (PEDOT) doped with polystyrene sulfonate (PSS), is also widely used as a hole transport layer (HTL) in perovskite solar cells. However, it results in a lower open circuit voltage $\mathrm{V}_{o c}$ compared to Spiro-OMeTAD [18].

Poly (3-hexylthiophene-2,5-diyl) (P3HT) is a low-cost polymer which is also used as a hole transporting material in perovskite solar cells [18]. When gold nanoparticles (Au-NPs) are added to the P3HT matrix (composite P3HT: Au-NPs), the efficiency of the cell increased from $7.81 \%$ to $10.71 \%$ [18]. This result is explained by the increase in the electrical conductivity and the mobility of the carriers, which becomes four times higher than that of the P3HT film alone.

\section{Back contact}

The most commonly used metals for back contact in perovskite solar cells are gold ( $\mathrm{Au}$ ) and silver (Ag). They present high conductivity and high reflectivity. Silver is however reactive with respect to perovskite [2]. Carbon materials, on the other hand, demonstrated a high potential to substitute metals and can improve the stability of the cells because of their water repellent layer [53].

\section{Substrates}

Low processing temperatures of perovskite materials have offered the possibility to use substrates other than glass, and specifically transparent flexible substrates [2] such as poly (ethyleneterephthalate) (PET) / ITO, polyethylenenaphthalate (PEN) / ITO, PET / IZO, PET / AZO / Ag / AZO.

\section{Factor influencing the stability of the perovskite}

Despite their high efficiency, the stability issue of solar cells is the major obstacle to commercialization of this technology. Moisture, UV-light and temperature are the main factors influencing the degradation of organometal halide perovskites.

\section{Moisture}

Yang et al. studied the influence of relative humidity (RH) on the perovskite layer degradation. They demonstrated, that higher RH values cause a more rapid reduction in film absorption. As shown in the Figure 6, this reaction occurs

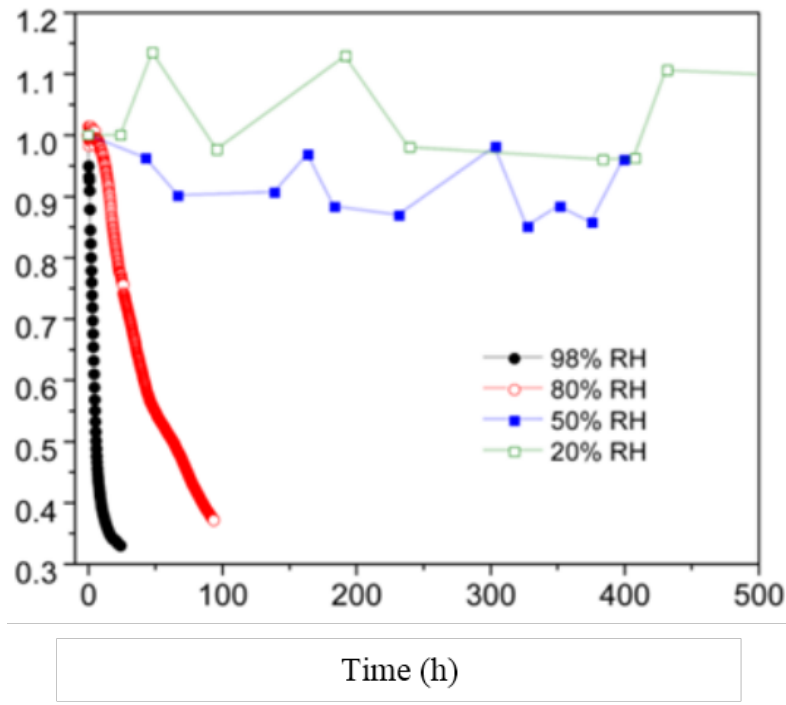

Figure 6: Effect of the moisture on the stability of the perovskite solar cells [30] 
extremely quickly for the $98 \% \mathrm{RH}$, for which the absorption is reduced to half of its original value after only $4 \mathrm{~h}$. However, for the low RH (20\%), extrapolation of the degradation curve suggests this would take $10,000 \mathrm{~h}$. This experiment was repeated for various carrier gases $\left(\mathrm{N}_{2}\right.$ or air $)$ with no significant changes in the degradation of the absorbance. This indicates that the main cause of degradation in the perovskite film, is the presence of moisture [20].

Moreover, Zhou et al. showed that, a relative humidity less than $30 \%$ during cell fabrication boosts the performance of the device due to the amelioration crystal morphology [54].

Noh et al. investigated the stoichiometry of $\operatorname{MAPb}\left(\mathrm{I}_{1-x} \mathrm{Br}_{x}\right)_{3}$ perovskites. As a result, the devices containing $\mathrm{Br}$ presented an improved stability. The degradation monitoring was carried in 35\% humidity for 20 days except at the 4th day where it was increased to $55 \%$ (Figure 7). As result, for $\mathrm{x}=0$ and $\mathrm{x}=0.06$, a significant degradation of the device was observed. However, for $\mathrm{x}=0.2$ and $\mathrm{x}=0.29$, the efficiency of the devices stayed almost constant during the whole period of monitoring [21].

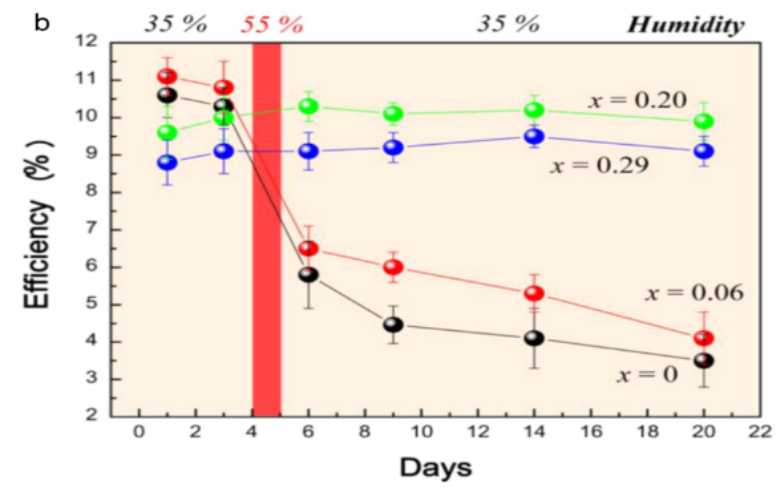

Figure 7: The effect of the stoichiometry of the perovskite MAPb(I1$\mathrm{xBrx}) 3$ layer on the stability of the devices [21]

These observations can be explained by the fact that in the presence of moisture, the perovskite layer is decomposed following Eq. (1). Subsequently, methylammonium iodide produces $\mathrm{CH}_{3} \mathrm{NH}_{2}$ and $\mathrm{HI}$ according to Eq. (2). $\mathrm{HI}$ on the other hand, is degraded in presence of oxygen according to Eq. (3), or UV-light according to Eq. (4) [55]:

$$
\begin{gathered}
\mathrm{CH}_{3} \mathrm{NH}_{3} \mathrm{PbI}_{3}(\mathrm{~s}) \rightleftarrows \mathrm{PbI}_{2}(\mathrm{~s})+\mathrm{CH}_{3} \mathrm{NH}_{3} \mathrm{I}(\mathrm{aq}) \\
\mathrm{CH}_{3} \mathrm{NH}_{3} \mathrm{I}(\mathrm{aq}) \rightleftarrows \mathrm{CH}_{3} \mathrm{NH}_{2}(\mathrm{aq})+\mathrm{HI}(\mathrm{aq}) \\
4 \mathrm{HI}(\mathrm{aq})+\mathrm{O}_{2}(\mathrm{~g}) \rightleftarrows 2 \mathrm{I}_{2}(\mathrm{~s})+2 \mathrm{H}_{2} \mathrm{O}(\mathrm{l}) \\
2 \mathrm{HI}(\mathrm{aq}) \rightleftarrows \mathrm{H}_{2}(\mathrm{~g})+\mathrm{I}_{2}(\mathrm{~s})
\end{gathered}
$$

\section{UV light}

PSCs with a $\mathrm{TiO}_{2}$ layer exhibit UV-induced degradation. Indeed, Leijtens et al. [4] measured the variation of the cell efficiency during 5 hours for encapsulated, nonencapsulated devices and encapsulated devices with a UV filter. As shown Figure 8 [4], the encapsulated device with UV filter exhibited better stability. However, the encapsulated cell without a UV filter is degraded at a faster rate that the non-encapsulated devices [4].

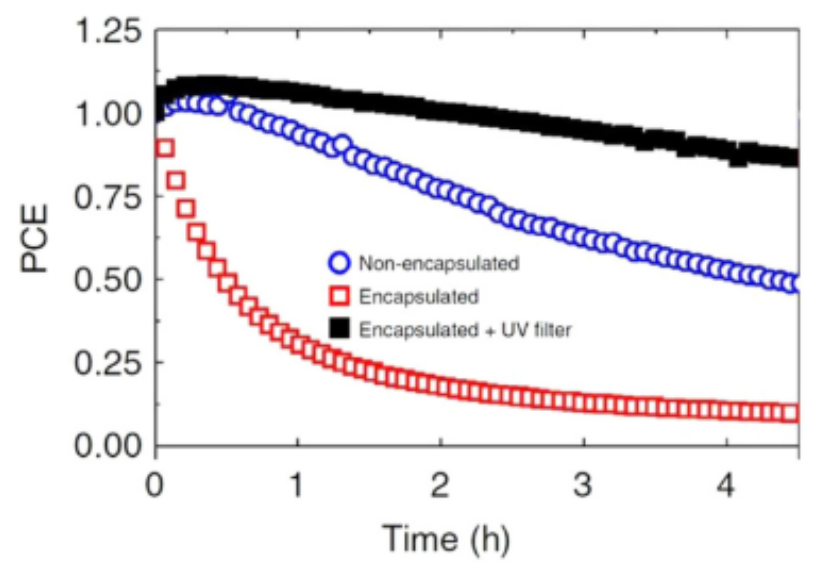

Figure 8: The effect of the encapsulation and UV filter on the Perovskite solar cells degradation [21]

\section{Temperature}

The thermal degradation of perovskite layers depends on their composition. Indeed, Tan et al. demonstrated a noticeable degradation of $\mathrm{CH}_{3} \mathrm{NH}_{3} \mathrm{PbI}_{3-x} \mathrm{Cl}_{x}$ perovskite at $100^{\circ} \mathrm{C}[56]$.

However, Misra et al. showed that sealed $\mathrm{CH}_{3} \mathrm{NH}_{3} \mathrm{PbBr}_{3}$ devices did not degrade during the accelerated aging tests, as opposed to the sealed $\mathrm{CH}_{3} \mathrm{NH}_{3} \mathrm{PbI}_{3}$ device which underwent degradation after $60 \mathrm{~min}$ at temperatures between $44^{\circ} \mathrm{C}$ and $55^{\circ} \mathrm{C}$ [57]. In addition, Eperon et al. [58] and Aharon et al. [5] showed that the thermal stability of formamidinium-based devices is higher than the methyl-ammonium-based ones, since the decomposition of $\left(\mathrm{HC}\left(\mathrm{NH}_{2}\right)_{2} \mathrm{PbI}_{3}\right)$ perovskite starts at $290^{\circ} \mathrm{C}$, while the degradation $\mathrm{CH}_{3} \mathrm{NH}_{3} \mathrm{PbI}_{3}$ perovskite start at $\sim 230^{\circ} \mathrm{C}$. 


\section{Improving the stability of the perovskite solar cells}

Perovskite is a fragile water-soluble material, which presents therefore a rapid and irreversible degradation. Several solutions have been proposed to improve the stability of the cells. In particular, the partial substitution of iodine by bromine improves the stability of the hybrid perovskite [59]. Mckeee et al showed that the mixed bromide-

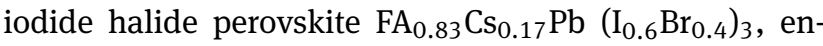
hances the photo-stability and the thermal stability of cells made with this absorber [60]. In addition, the incorporation of Cesium (Cs) in the A position of the perovskite structure demonstrated a better stability [4]. Lee and al elaborated $\mathrm{FA}_{0.9} \mathrm{Cs}_{0.1} \mathrm{PbI}_{3}$, by substituting $10 \%$ of $\mathrm{FA}$ by Cs in the structure of $\mathrm{FAPbI}_{3}$ perovskite. This combination allowed to improve the efficiency to $10 \%$, with a better stability.

The two-dimensional (2D) perovskites were shown be good candidates to overcome stability problems. They are obtained by the incorporation of voluminous organic cations between the different $\mathrm{MX}_{6}$ octahedra layers in the three dimension perovskite $\mathrm{APbX}_{3}$ [61].

Furthermore, grain boundaries are potential recombination centers for charge carriers, which reduce the performance of perovskites over time. An interesting solution to overcome this problem is to improve the crystalline quality of perovskites by developing large grains during the crystallization at appropriate temperatures [31]. Indeed, W. Nie et al. demonstrated that heating the substrate to a temperature of $190^{\circ} \mathrm{C}$ leads to perovskite films with large grains. On the other hand, encapsulation is one way to protect the cells against external factors [22].

The auto repair of the photovoltaic cells in the dark is among the solutions that were proposed to recover the initial efficiency of the perovskite cells. Indeed, during the day, electrical charges are trapped in the defects, which disrupts the continuous flow of these carriers. The darkness then allows to evacuate these trapped charges, with the consequence of recovering the initial efficiencies of the cells [62].

To overcome the degradation of the perovskite devices induced by UV-sensibility of the $\mathrm{TiO}_{2}$ layer, several works focused on the substitution of this layer. Indeed, Bera et al. proposed $\mathrm{Zn}_{2} \mathrm{SnO}_{4}$ as electron transporter layers, allowing an efficiency of $13.3 \%$ and one-month stability without any encapsulation [63]. Furthermore, Ito et al. used $\mathrm{Sb}_{2} \mathrm{~S}_{3}$ as a blocking layer to reduce UV-induced degradation. In fact, the device with $\mathrm{Sb}_{2} \mathrm{~S}_{3}$ maintained almost $65 \%$ of its initial efficiency without encapsulation, as opposed to one without $\mathrm{Sb}_{2} \mathrm{~S}_{3}$ under the same conditions of exposure [64]. Furthermore, Chander et al. proposed the use of a UV filter [65].

\section{Tandem cells based on perovskite}

The efficiency of cells can be improved by combining two solar cells with complementary absorption regions of the solar spectrum, in a tandem structure. The two sub-cells are can be stacked horizontally or vertically (on top of one another). The top cell, with the larger band-gap between $1.5-1.8 \mathrm{eV}$ is stacked on the bottom cell with a smaller bandgap between 0.9-1.2 eV [51]. Thus, the tandem cell can absorb a greater portion of the solar spectrum, which leads to a significant increase in its conversion efficiency $[2,51,52]$.

\subsection{Working mechanism}

When the tandem cell is exposed to light, the top cell absorbs and converts high-energy photons (Figure 9), leaving photons of lower energy to be harvested by the bottom cell $[51,66]$.

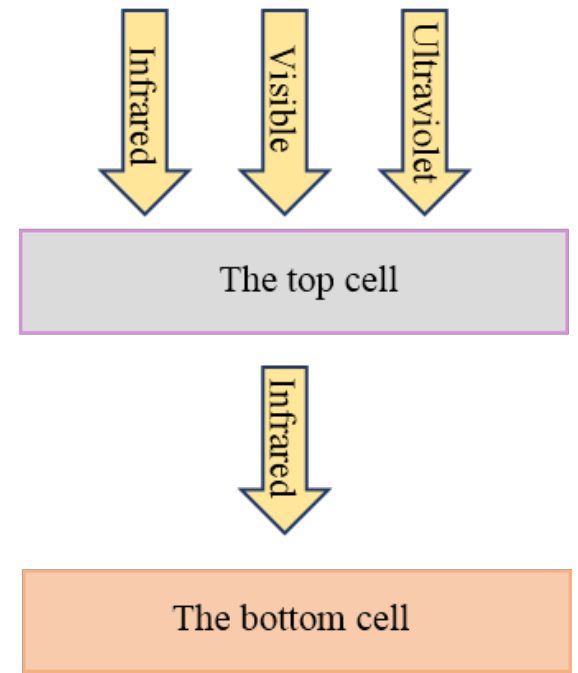

Figure 9: Principle of the tandem cell

\subsection{Tandem cell configurations}

The tandem cells are generally monolithic or four-terminal configurations, other designs are less used [67]. 
In the four-terminal configuration, the sub-cells are fabricated independently and are mechanically stacked one over the other $[26,51,66]$. However, in the twoterminal tandem configuration, called also monolithic, the top cell is directly deposited on the bottom one, which requires fewer transparent conductive electrodes and makes them easier to be integrated in a module $[26,66]$. Thus, the parasitic absorption due to these electrodes is avoided and the fabrication costs are lower thanks to the reduction of the manufacturing steps [26]. However, this configuration often produces lower performances compared to the four-terminal tandem cells. The two sub-cells in the monolithic tandem must be optimized in such a way as to produce the same current at their respective maximum power-point. In addition, the top cell must be deposited at low temperatures to avoid damages to the bottom cell [26] Moreover, the typically opaque back electrode of the top sub-cell must be replaced by a conductive layer possessing a high transparency throughout the visible and nearinfrared spectral region, so that it allows light to pass to the absorber of the bottom sub-cell [66].

The coupling between the two subcells can be achieved by a $\mathrm{P}+\mathrm{N}+$ type tunnel junction or by a very thin oxide layer, allowing the passage of the carriers by tunneling $[23,52]$.

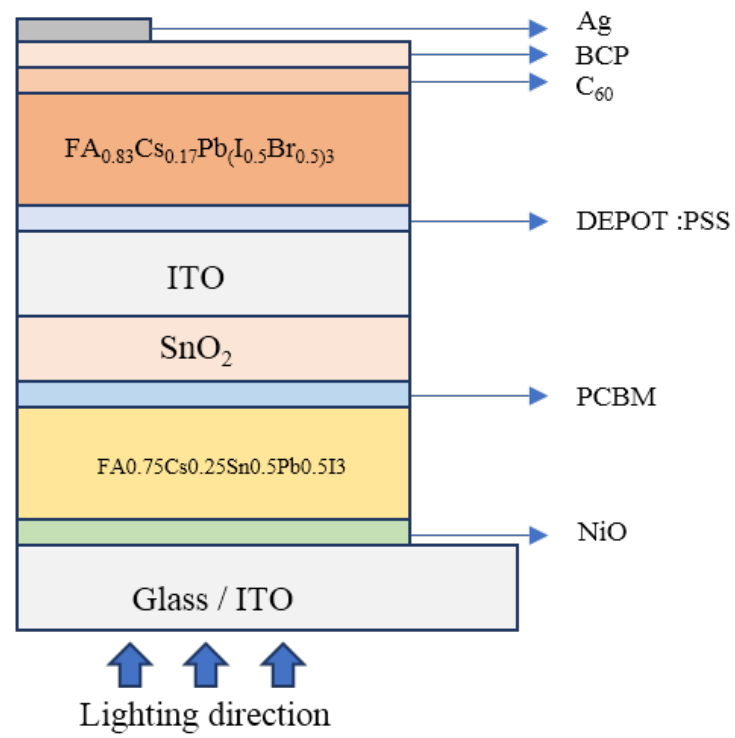

\subsection{Tandem cells containing the perovskite subcell}

The special and unique properties of perovskites make them attractive as a top cell in tandem configuration. Indeed, several cells couplings have been developed, either in monolithic or in four-terminal tandem configurations, notably perovskite / perovskite, perovskite / Copper Indium Gallium Selenide (CIGS), and monolithic perovskite / silicon heterojunction cells.

\section{The Perovskite / Perovskite tandem cells}

The ability to adjust the band gap and electronic properties of perovskites makes the perovskite / perovskite tandem cells the likely candidates for improving solar cells performances and for lowering fabrication costs [23]. Some configurations of these tandem cells are presented below.

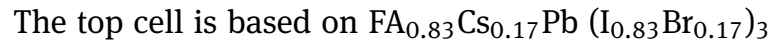
perovskite absorber, with a band gap of $1.6 \mathrm{eV}$ for the four-terminal tandem cell. A larger band gap up to 1.8 $\mathrm{eV}$ absorber $\mathrm{FA}_{0.83} \mathrm{Cs}_{0.17} \mathrm{~Pb}\left(\mathrm{I}_{0.5} \mathrm{Br}_{0.5}\right)_{3}$ was used for the monolithic tandem cells [23]. Furthermore, the absorber $\mathrm{FA}_{0.75} \mathrm{Cs}_{0.25} \mathrm{Sn}_{0.5} \mathrm{~Pb}_{0.5} \mathrm{I}_{3}$ with a band gap of $1.2 \mathrm{eV}$ was developed and used as an absorber for the bottom cell for the two tandem configurations. The configuration of the both tandem cells is illustrated in the Figure 10.
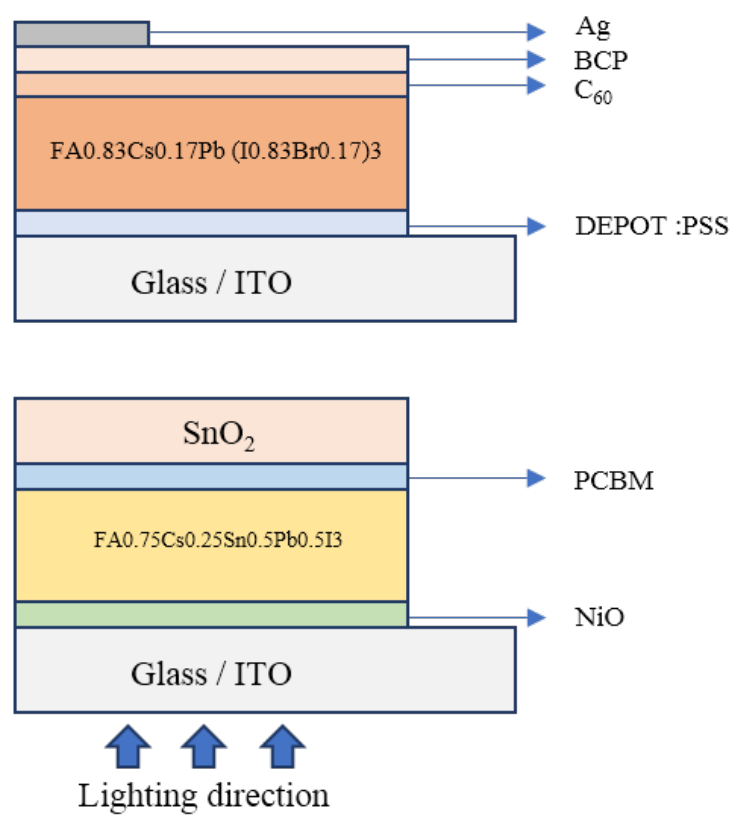

Figure 10: Monolithic and four-terminal Perovskite / Perovskite tandem cell are presented respectively 
Table 2: Characteristics of the Perovskite / Perovskite tandem cells developed in monolithic and in four-terminal configuration, as well as those of the constituent sub-cells, with an active area of $0.2 \mathrm{~cm}^{2}$ [23].

\begin{tabular}{lccccc}
\hline Cells & $\mathrm{J}_{s c}\left(\mathrm{~mA} / \mathrm{cm}^{2}\right)$ & $\mathrm{V}_{o c}(\mathrm{~V})$ & $\mathrm{FF}$ & $\eta(\%)$ & $\mathrm{SPO}$ \\
\hline Absorber cell of 1,2 eV (single junction) & 26,7 & 0,74 & 0,71 & 14,1 & 14,8 \\
Absorber cell of 1,8 eV (single junction) & 15,1 & 1,12 & 0,58 & 9,8 & 9,5 \\
Monolithic tandem & 14,5 & 1,66 & 0,7 & 16,9 & 17 \\
Absorber cell of 1,2 eV (4 terminal) & 7,9 & 0,74 & 0,73 & 4,4 & 4,5 \\
Absorber cell of 1,6 eV (4 terminal) & 20,3 & 0,97 & 0,79 & 15,7 & 15,8 \\
Four terminal tandem & & & & 20,1 & 20,3 \\
\hline
\end{tabular}

Thanks to the complementarity of the top and bottom cells, the efficiency of the monolithic tandem cell reached $17 \%$. The four-terminal configuration, on the other hand, offered an efficiency of $20.3 \%$ for cells with an active area of $0.2 \mathrm{~cm}^{2}$ [23]. The characteristics of the sub-cells and the tandem cells are summarized in the Table 2 [23]:

The characteristics of tandem cells with a larger area, of the order of one square centimeter, are smaller than those measured for the area of $0.2 \mathrm{~cm}^{2}$ [23]. The efficiency was $14.8 \%$ for the monolithic configuration and $9.5 \%$ for the four terminal one.

Several other perovskite materials were investigated by researchers. Especially, Rui Sheng et al. studied the perovskite / perovskite tandem cell using $\mathrm{MAPbBr}_{3}$ as the higher band-gap cell and $\mathrm{MAPbI}_{3}$ as the lower one. They demonstrated through simulations an efficiency of $25.9 \%$ for the monolithic tandem cell [68].

\section{Perovskite/ CIGS tandem cells}

CIGS is considered to be the best absorber in the family of I-III-VI2 semiconductors, made of elements from groups I, III and VI of the periodic table. It has a band gap between 1.24 and $1.3 \mathrm{eV}$ [69], which is considered as an optimum band gap for tandem cells [66]. In fact, the coupling of perovskite and CIGS sub-cells into tandem cells has resulted in cells with improved efficiencies [51].

In 2016, cells based on $\mathrm{Cu}(\mathrm{Ga}, \mathrm{In})(\mathrm{Se})_{2}$ absorber achieved an efficiencies of $21.0 \%$, an open circuit voltage of $0.757 \mathrm{~V}$, a short-circuit current density of $70 \mathrm{~mA} / \mathrm{cm}^{2}$ and a fill factor (FF) of $77.6 \%$, for a cell of about $1 \mathrm{~cm}^{2}$ [24]. Today, the record for CIGS-based cells has reached 23.4\% according to the National Renewable Energy Laboratory (NREL) efficiency chart [70].

The perovskite cell used in the one of the best perovskite/CIGS tandem cells has the following configuration: FTO / c-TiO $/ \mathrm{mp}-\mathrm{TiO}_{2}: \mathrm{CH}_{3} \mathrm{NH}_{3} \mathrm{PbI}_{3} / \mathrm{CH}_{3} \mathrm{NH}_{3} \mathrm{PbI}_{3}$ / spiroOMeTAD / $\mathrm{MoO}_{3}$ / ZnO: Al / MgF 2 [51]. A 16.1\% efficiency was attained with gold contact and $12.1 \%$ with the transparent one, which is adapted to the tandem concept since it transmits $71 \%$ of the photons with energy below the band gap (wavelengths 800 and $1000 \mathrm{~nm}$ ) to the CIGS bottom cell [51]. The CIGS bottom cell was prepared by co-evaporation and consists of the following stacks (Figure 11): substrate/Mo/CIGS/ CdS/ ZnO/ZnO:Al [51].

The CIGS cell exhibits a $18.4 \%$ power conversion efficiency which decreases to $7.4 \%$ when it is placed below the perovskite subcell, with an opening area of $0.213 \mathrm{~cm}^{2}$. This is due to the low illumination intensity, which induces a significant drop in current density as well as a slight decrease in open circuit voltage $\left(\mathrm{V}_{o c}\right)$ [51].

The four-terminal perovskite/CIGS tandem cell consists of coupling the perovskite top cell with the superstrate configuration and the CIGS bottom cell with the opposite configuration [51]. The resulting tandem cell is schematized in Figure 12.

The efficiency of the four-terminal tandem cell is the sum of the two efficiencies of the two sub-cells $[51,66]$. For this configuration, the efficiency of the tandem cell reached $19.5 \%$ as shown in the Table 3 [51]:

Table 3: The performances and efficiencies of the sub-cells, as well as the efficiency of the 4-terminal tandem cell [51].

\begin{tabular}{llcccc}
\hline Solar Cell & $\begin{array}{l}\mathbf{V}_{\text {oc }} \\
(\mathbf{m V})\end{array}$ & $J_{\mathbf{s c}}\left(\mathrm{mA} / \mathrm{cm}^{2}\right)$ & $\begin{array}{c}\mathrm{FF} \\
(\%)\end{array}$ & $\begin{array}{l}\boldsymbol{\eta} \\
(\%)\end{array}$ & Irradiance $\left(\mathbf{W} / \mathrm{cm}^{\mathbf{2}}\right)$ \\
\hline The perovskite top cell (transparent contact) & 1034 & 16,7 & 70,3 & 12,1 & 1000 \\
CIGS bottom cell (tandem) & 661 & 14,4 & 77,4 & 7,4 & 1000 \\
4-terminal tandem cell & & & & 19,5 & 1000 \\
\hline
\end{tabular}

$\mathrm{J}_{s c}$ : Short-circuit current density; FF: Fill factor

$\mathrm{V}_{o c}$ : Open-circuit voltage 


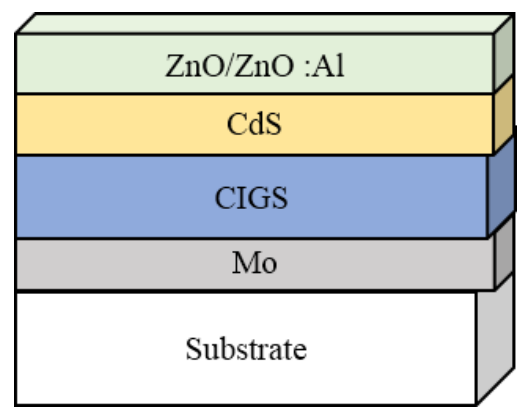

Figure 11: The configuration of the CIGS sub-cell

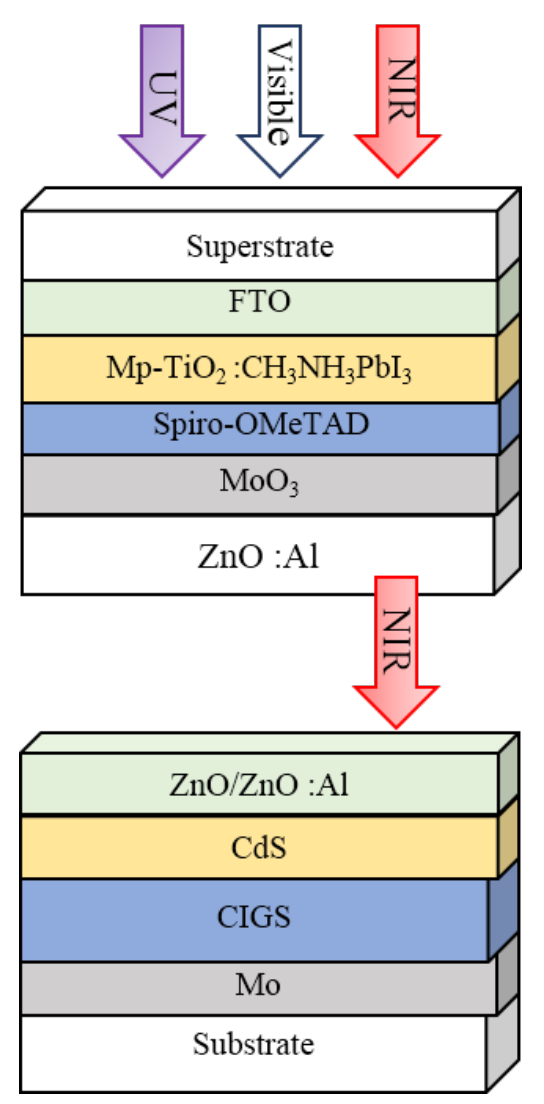

Figure 12: Four terminal perovskite / CIGS tandem cell structure

Actually, the record efficiency of this family of tandem cells achieved $24.6 \%$ [71]. Since they are made of thin film, they offer a variety of functional shapes and sizes, and consequently a great potential in several industrial applications.

\section{Perovskite/ Silicon tandem cells}

Over the past fifteen years, the efficiency of crystalline silicon solar cells has only slightly increased [26] and reached a record efficiency of $26.1 \%$ for crystalline single junction cells and $26.6 \%$ for heterojunction cells with interdigitated back contacts [70, 72]. This is close to the maximum theoretical efficiency for single junction silicon cells which is on the order of $29.4 \%$ [26].

The easiest way to exceed the theoretical limit with a reasonable cost is to couple the silicon cell with another low-cost cell, which contains an absorber material with a larger band gap [26]. The perovskite is a promising cell that perfectly meets this requirement. Enormous progress was made in this series of cells and efficiency of up to $25.2 \%$ were achieved [70].

Tandem cells based on perovskite and silicon consist in coupling these two complementary absorption materials, where the perovskite top cell has a wider band gap than that of the heterojunction silicon bottom cell [66].

Indeed, Loper et al. realized a four-terminal tandem cell with an efficiency of $13.4 \%$, where the efficiency of the perovskite top cell is $6.2 \%$ while that of the crystalline silicon heterojunction bottom cell is $7.2 \%$ [73].

The structure, shown in the Figure 13, resulted in $18.1 \%$ efficiency [52]. The perovskite used in this tandem configuration has an efficiency of $10.4 \%$ and consists of the following stacks: $\mathrm{SnO}_{2} /(\mathrm{MA})_{x}(\mathrm{FA})_{1-x} \mathrm{PbI}_{x} \mathrm{Br}_{3-\chi} /$ SpiroOMeTAD $/ \mathrm{MoO}_{3} / \mathrm{ITO}$ [52]. However, the silicon heterojunction bottom cell is of standard configuration [52], with a $15.7 \%$ efficiency.

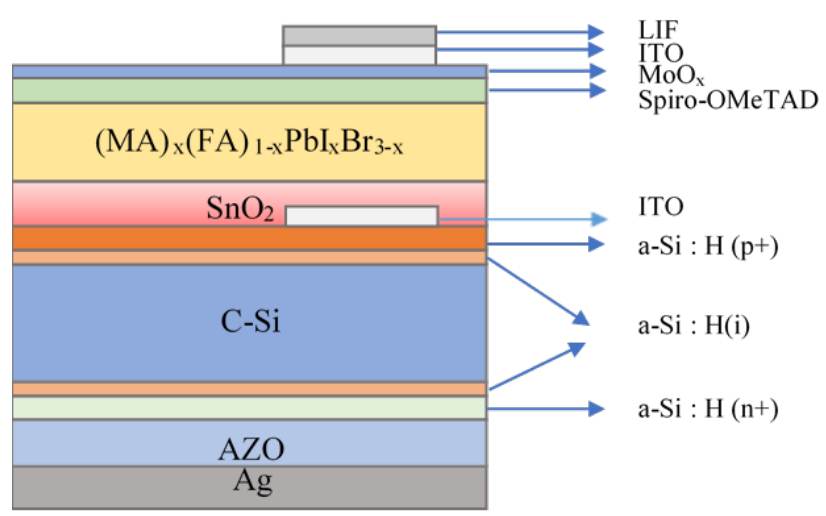

Figure 13: Monolithic perovskite / silicon tandem cell structure

This combination made it possible to achieve an efficiency of $19.9 \%$, an open-circuit voltage of $1.785 \mathrm{~V}$, a shortcircuit current density of $14 \mathrm{~mA} / \mathrm{cm}^{2}$ and a fill factor of $79.5 \%$. However, the stabilized power output of this tandem cell is only of $18.1 \%$ [52].

In 2016, S. De Wolf et al. developed perovskite/Silicon monolithic tandem cell with a $21.2 \%$ efficiency, made of a silicon heterojunction bottom-cell with a standard configuration, reaching $16.8 \%$ efficiency and of perovskite top- 
cell with an efficiency of $14.5 \%$, composed of several stacks $\mathrm{IZO} / \mathrm{PEIE} / \mathrm{PCBM} / \mathrm{CH}_{3} \mathrm{NH}_{3} \mathrm{PbI}_{3} /$ spiro OMeTAD/ $\mathrm{MoO}_{x}$ / IO: $\mathrm{H} / \mathrm{ITO}$ [26]. The monolithic tandem cell is illustrated in the Figure 14.

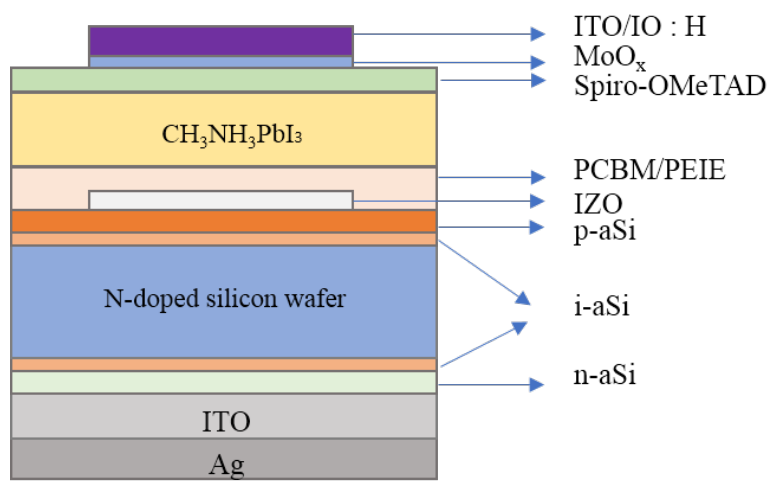

Figure 14: Monolithic perovskite / silicon tandem cell structure

This configuration lead respectively to $18,1 \%$ and $17.2 \%$ efficiencies for $0,17 \mathrm{~cm}^{2}$ and $1.22 \mathrm{~cm}^{2}$ aperture areas, respectively. Furthermore, this monolithic tandem cell reached a record efficiency of $19.2 \%$ for an aperture area of $1.22 \mathrm{~cm}^{2}$ and $21.2 \%$ for $0.17 \mathrm{~cm}^{2}$, using an antireflective layer [26].

In 2017, Bush et al.. realized a monolithic perovskite / silicon tandem cell with a record efficiency of $23.6 \%$ for an area of $1 \mathrm{~cm}^{2}$ [25]. Nevertheless, the world record is of $25.2 \%$ for the four-terminal tandem cell [74]. The perovskite sub-cell used in the monolithic tandem configuration consists of the following stacks: Glass / ITO / NiO $/ \mathrm{Cs}_{0.17} \mathrm{FA}_{0.83} \mathrm{~Pb}\left(\mathrm{Br}{ }_{0.17} \mathrm{I}{ }_{0.83}\right)_{3} / \mathrm{LiF} / \mathrm{PCBM} / \mathrm{SnO}_{2} /$ ZTO / ITO / LiF / Ag [25]. However, the silicon bottom cell is of standard configuration. This combination is the best monolithic tandem cell, certified by NREL, where, the open circuit voltage is $1.65 \mathrm{~V}$, the short circuit current density is $18.1 \mathrm{~mA} / \mathrm{cm}^{2}$, the fill factor reaches $79.0 \%$, thus allowing a record efficiency of $23.6 \%$ [25]. The structure of this cell is shown in the Figure 15.

\section{Conclusion}

Perovskite solar cells are increasingly becoming competitive with silicon technology in terms of efficiency and cost. Efficiency in excess of $25 \%$ has been reached in only seven years of research with simple and low-cost fabrication techniques. In addition, they offer multiple choices of materials, processing methods and structures. However,

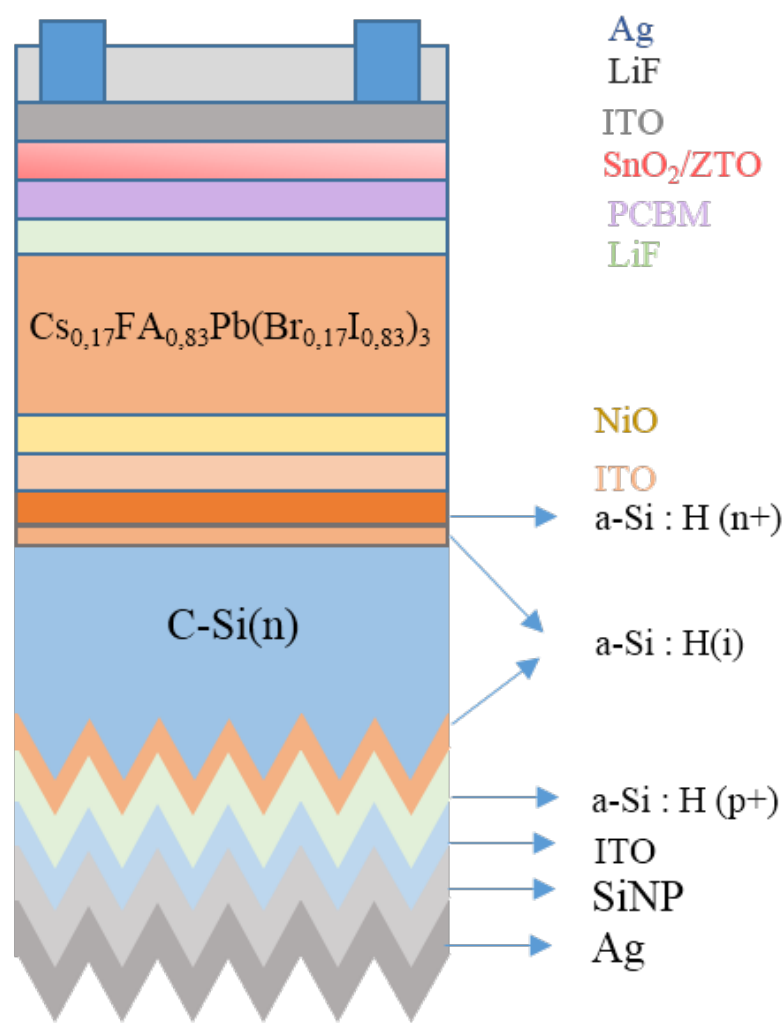

Figure 15: The record monolithic perovskite / silicon tandem cell structure

the stability issue is the major obstacle to the commercialization of this technology. Nevertheless, the selection of the materials, the components of the cell and the appropriate protection mean can lead to a significant improvement of the stability of the devices.

Furthermore, the perovskite solar cell showed a great potential as the top cell in tandem configurations. This recent approach became an attractive way to improve the performances of the conventional technologies. However, several means of improvement remain to be investigated to approach the theoretical limit which is on the order of $46 \%$ [75], while maintaining a competitive advantage over the most efficient cells, but which are technologically the most expensive.

\section{References}

[1] Nazeeruddin, M. K. and H. Snaith. Methylammonium lead triiodide perovskite solar cells: A new paradigm in photovoltaics. MRS Bulletin, Vol. 40, No. 8, 2015, pp. 641-645.

[2] Chen, Q., N. De Marco, Y. M. Yang, T.-B. Song, C.-C. Chen, H. Zhao et al. Under the spotlight: The organic-inorganic hybrid halide perovskite for optoelectronic applications. Nano Today, Vol. 10, 
No. 3,2015, pp. 355-396.

[3] Wehrenfennig, C., G. E. Eperon, M. B. Johnston, H. J. Snaith and L. M. Herz. High charge carrier mobilities and lifetimes in organolead trihalide perovskites. Advanced Materials, Vol. 26, No. 10, 2014, pp. 1584-1589.

[4] Wang, D., M. Wright, N. K. Elumalai and A. Uddin. Stability of perovskite solar cells. Solar Energy Materials and Solar Cells, Vol. 147, 2016, pp. 255-275.

[5] Zuo, C., H. J. Bolink, H. Han, J. Huang, D. Cahen and L. Ding. Advances in perovskite solar cells. Advanced Science, Vol. 3, No. 7, 2016, pp. 1500324.

[6] Beal, R. E., D. J. Slotcavage, T. Leijtens, A. R. Bowring, R. A. Belisle, W. H. Nguyen et al. Cesium lead halide perovskites with improved stability for tandem solar cells. The Journal of Physical Chemistry Letters, Vol. 7, No. 5, 2016, pp. 746-751.

[7] Saliba, M., T. Matsui, J.Y Seo, K. Domanski, J.P Correa-Baena, M. K. Nazeeruddin et al. Cesium-containing triple cation perovskite solar cells: improved stability, reproducibility and high efficiency. Energy \& Environmental Science, Vol. 9, No. 6, 2016, pp. 19891997.

[8] Park, N.-G., Methodologies for high efficiency perovskite solar cells. Nano Convergence, Vol. 3, No. 1, 2016, pp. 15.

[9] Liu, Y., Z. Hong, Q. Chen, W. Chang, H. Zhou, T.-B. Song et al. Integrated perovskite/bulk-heterojunction toward efficient solar cells. Nano Letters, Vol. 15, No. 1, 2015, pp. 662-668.

[10] Im, J.H., I.H. Jang, N. Pellet, M. Gratzel and N.G. Park. Growth of $\mathrm{CH} 3 \mathrm{NH} 3 \mathrm{~Pb} 33$ cuboids with controlled size for high-efficiency perovskite solar cells. Nature Nanotechnology, Vol. 9, No. 11, 2014, pp. 927-932.

[11] Liang, Z., S. Zhang, X. Xu, N. Wang, J. Wang, X. Wang et al. A large grain size perovskite thin film with a dense structure for planar heterojunction solar cells via spray deposition under ambient conditions. RSC Advances, Vol. 5, No. 74, 2015, pp. 60562-60569.

[12] Razza, S., S. Castro-hermosa, A. Di Carlo and T. M. Brown. Research Update: Large-area deposition, coating, printing, and processing techniques for the upscaling of perovskite solar cell technology. APL Materials, Vol. 4, No. 9, 2016, pp. 091508.

[13] Song, T.-B., Q. Chen, H. Zhou, C. Jiang, H.-H. Wang, Y. M. Yang et al. Perovskite solar cells: film formation and properties. Journal of Materials Chemistry A, Vol. 3, No. 17, 2015, pp. 9032-9050.

[14] Gheno, A., T. T.T. Pham, C. Di Bin, J. Bouclé, B. Ratier and S. Vedraine. Printable W03 electron transporting layer for perovskite solar cells: Influence on device performance and stability. Solar Energy Materials and Solar Cells, Vol. 161, 2017, pp. 347-354.

[15] Mahmood, K., S. Sarwar and M. T. Mehran. Current status of electron transport layers in perovskite solar cells: materials and properties. RSC Advances, Vol. 7, No. 28, 2017, pp. 17044-17062.

[16] Zhao, X., H. Shen, Y. Zhang, X. Li, X. Zhao, M. Tai et al. Aluminumdoped zinc oxide as highly stable electron collection layer for perovskite solar cells. ACS Applied Materials \& Interfaces, Vol. 8, No. 12, 2016, pp. 7826-7833.

[17] Son, D.Y., J.H. Im, H.S. Kim and N. Park. $11 \%$ efficient perovskite solar cell based on $\mathrm{ZnO}$ nanorods: an effective charge collection system. The Journal of Physical Chemistry C, Vol. 118, No. 30, 2014, pp. 16567-16573.

[18] Wang, J.Y., F.C. Hsu, J.Y. Huang, L. Wang and Y.F. Chen. Bifunctional polymer nanocomposites as hole-transport layers for efficient light harvesting: application to perovskite solar cells. ACS Applied Materials \& Interfaces, Vol. 7, No. 50, 2015, pp. 27676 -
27684.

[19] Christians, J. A., R.C.M. Fung and P.V. Kamat. An inorganic hole conductor for organo-lead halide perovskite solar cells. Improved hole conductivity with copper iodide. Journal of the American Chemical Society, Vol. 136, No. 2, 2014, pp. 758-764.

[20] Yang, J., B. D. Siempelkamp, D. Liu and T.L. Kelly. Investigation of $\mathrm{CH} 3 \mathrm{NH} 3 \mathrm{Pbl} 3$ degradation rates and mechanisms in controlled humidity environments using in situ techniques. ACS Nano, Vol. 9, No. 2, 2015, pp. 1955-1963.

[21] Noh, J. H., S. H. Im, J. H. Heo, T. N. Mandal and S.I. Seok. Chemical management for colorful, efficient, and stable inorganic-organic hybrid nanostructured solar cells. Nano Letters, Vol. 13, No. 4, 2013, pp. 1764-1769.

[22] Cui, J., P. Li, Z. Chen, K. Cao, D. Li, J. Han et al. Phosphor coated $\mathrm{NiO}$-based planar inverted organometallic halide perovskite solar cells with enhanced efficiency and stability. Applied Physics Letters, Vol. 109, No. 17, 2016, pp. 171103.

[23] Eperon, G. E., T. Leijtens, K. A. Bush, R. Prasanna, T. Green, J. T.W. Wang et al. Perovskite-perovskite tandem photovoltaics with optimized band gaps. Science, Vol. 354, No. 6314, 2016, pp. 861-865.

[24] Rand, B. P., J. Genoe, P. Heremans and J. Poortmans. Solar cells utilizing small molecular weight organic semiconductors. Progress in Photovoltaics: Research and Applications, Vol. 15, No. 8, 2007, pp. 659-676.

[25] Bush, K.A., A.F. Palmstrom, Z.J.Yu, M. Boccard, R. Cheacharoen, J.P. Mailoa et al. $23.6 \%$-efficient monolithic perovskite/silicon tandem solar cells with improved stability. Nature Energy, Vol. 2, No. 4, 2017, pp. 1-7.

[26] Werner, J., C.H. Weng, A. Walter, L. Fesquet, J.P. Seif, S. De Wolf et al. Efficient monolithic perovskite/silicon tandem solar cell with cell area $1 \mathrm{~cm}^{2}$. The Journal of Physical Chemistry Letters, Vol. 7, No. 1, 2016, pp. 161-166.

[27] Muller, A., M. Ghosh, R. Sonnenschein and P. Woditsch. Silicon for photovoltaic applications. Materials Science and Engineering: B, Vol. 134, No. 2-3, 2006, pp. 257-262.

[28] Reber, S. and W. Wettling. High-temperature processing of crystalline silicon thin-film solar cells. Applied Physics A, Vol. 69, No. 2, 1999, pp. 215-220.

[29] Neuhaus, D.H. and A. Münzer. Industrial silicon wafer solar cells. Advances in Optoelectronics, Vol. 2007, 2007, pp. 1-15.

[30] Song, Z., S. C. Watthage, A. B. Phillips and M. J. Heben. Pathways toward high-performance perovskite solar cells: review of recent advances in organo-metal halide perovskites for photovoltaic applications. Journal of Photonics for Energy, Vol. 6, No. 2, 2016, pp. 022001.

[31] Nie, W., H. Tsai, R. Asadpour, J.-C. Blancon, A. J. Neukirch, G. Gupta et al. High-efficiency solution-processed perovskite solar cells with millimeter-scale grains. Science, Vol. 347, No. 6221, 2015, pp. 522-525.

[32] Rohella, R. S., S. K. Panda and P. Das. Perovskite solar cell-a source of renewable green power. International Journal of Scientific and Research Publications, Vol. 5, 2015, pp. 2250-3153.

[33] Ono, L.K., M.R. Leyden, S. Wang and Y. Qi. Organometal halide perovskite thin films and solar cells by vapor deposition. Journal of Materials Chemistry A, Vol. 4, No. 18, 2016, pp. 6693-6713.

[34] Zhao, Q., G.R Li, J. Song, Y. Zhao, Y. Qiang and X.P. Gao. Improving the photovoltaic performance of perovskite solar cells with acetate. Scientific Reports, Vol. 6, 2016, pp. 38670. 
[35] Li, B., J. Tian, L. Guo, C. Fei, T. Shen, X. Qu et al. Dynamic growth of pinhole-free conformal $\mathrm{CH} 3 \mathrm{NH} 3 \mathrm{~Pb} 33$ film for perovskite solar cells. ACS Applied Materials \& Interfaces, Vol. 8, No. 7, 2016, pp. 4684-4690.

[36] Babayigit, A., A. Ethirajan, M. Muller and B. Conings. Toxicity of organometal halide perovskite solar cells. Nature Materials, Vol. 15, No. 3, 2016, pp. 247-251.

[37] Binek, A., M. L. Petrus, N. Huber, H. Bristonw, Y. Hu, T. Bein et al. Recycling perovskite solar cells to avoid lead waste. ACS Applied Materials \& Interfaces, Vol. 8, No. 20, 2016, pp. 12881-12886.

[38] Kojima, A., K. Teshima, Y. Shirai and T. Miyasaka. Organometal halide perovskites as visible-light sensitizers for photovoltaic cells. Journal of the American Chemical Society, Vol. 131, No. 17, 2009, pp. 6050-6051.

[39] Grätzel, M., The light and shade of perovskite solar cells. Nature Materials, Vol. 13, No. 9, 2014, pp. 838-842.

[40] Bui, T.T. and F. Goubard. Matériaux de transport de trous à base de petites molécules organiques pour cellules photovoltaïques hybrides solides. Matériaux \& Techniques, Vol. 101, No. 1, 2013, pp. 102.

[41] Lee, M. M., J.Teuscher, T. Miyasaka, T. N. Murakami and H. J. Snaith. Efficient hybrid solar cells based on mesosuperstructured organometal halide perovskites. Science, Vol. 338, No. 6107, 2012, pp. 643-647.

[42] Burschka, J., N. Pellet, S.-J. Moon, R. Humphry-Baker, P. Gao, M. $K$. Nazeeruddin et al. Sequential deposition as a route to highperformance perovskite-sensitized solar cells. Nature, Vol. 499, No. 7458, 2013, pp. 316-319.

[43] Wu, W.Q., D. Chen, R. A. Caruso and Y.B. Cheng. Recent progress in hybrid perovskite solar cells based on n-type materials. Journal of Materials Chemistry A, Vol. 5, No. 21, 2017, pp. 10092-10109.

[44] Chen, W., X. Yin, M. Que, H. Xie, J. Liu, C. Yang et al. A comparative study of planar and mesoporous perovskite solar cells with printable carbon electrodes. Journal of Power Sources, Vol. 412, 2019, pp. 118-124.

[45] Fakharuddin, A., F. Di Giacomob, I. Ahmed, Q. Wali, T. M. Brown and R. Jose. Role of morphology and crystallinity of nanorod and planar electron transport layers on the performance and long term durability of perovskite solar cells. Journal of Power Sources, Vol. 283, 2015, pp. 61-67.

[46] Noh, M. F. M., C. H. Teh, R. Daik, E. L. Lim, C. C. Yap, M. A. Ibrahim et al. The architecture of the electron transport layer for a perovskite solar cell. Journal of Materials Chemistry C, Vol. 6, No. 4, 2018, pp. 682-712.

[47] Correa-Baena, J.P., L. Steier, W. Tress, M. Saliba, S. Neutzner, T. Matsui et al. Highly efficient planar perovskite solar cells through band alignment engineering. Energy \& Environmental Science, Vol. 8, No. 10, 2015, pp. 2928-2934.

[48] Anaraki, E.H., A. Kermanpur, L. Steier, K. Domanski, T. Matsui, W. Tress et al. Highly efficient and stable planar perovskite solar cells by solution-processed tin oxide. Energy \& Environmental Science, Vol. 9, No. 10, 2016, pp. 3128-3134.

[49] Kim, H.S. and N.G. Park. Parameters affecting I-V hysteresis of CH3NH3Pbl3 perovskite solar cells: effects of perovskite crystal size and mesoporous TiO2 layer. The Journal of Physical Chemistry Letters, Vol. 5, No. 17, 2014, pp. 2927-2934.

[50] Noel, N.K., A. Abate, S.D. Stranks, E.S. Parrott, V.M. Burlakov, A. Goriely et al. Enhanced photoluminescence and solar cell performance via Lewis base passivation of organic-inorganic lead halide perovskites. ACS Nano, Vol. 8, No. 10, 2014, pp. 9815-
9821.

[51] Kranz, L., A. Abate, T. Feurer, F. Fu, E. Avancini, J. Löckinger et al. High-efficiency polycrystalline thin film tandem solar cells. The Journal of Physical Chemistry Letters, Vol. 6, No. 14, 2015, pp. 2676-2681.

[52] Albrecht, S., M. Saliba, J. P. Correa-Baena, F. Lang, L. Kegelmann, M. Mews et al. Monolithic perovskite/silicon-heterojunction tandem solar cells processed at low temperature. Energy \& Environmental Science, Vol. 9, No. 1, 2016, pp. 81-88.

[53] Zhang, J. Roles of the $\mathrm{n}$-type oxide layer in hybrid perovskite solar cells. Doctoral dissertation. Pierre and Marie Curie University, Paris, 2015.

[54] Mesquita, I., L. Andrade and A. Mendes. Perovskite solar cells: Materials, configurations and stability. Renewable and Sustainable Energy Reviews, Vol. 82, 2018, pp. 2471-2489.

[55] Niu, G., X. Guo and L. Wang. Review of recent progress in chemical stability of perovskite solar cells. Journal of Materials Chemistry A, Vol. 3, No. 17, 2015, pp. 8970-8980.

[56] Tan, K.W., D.T. Moore, M. Saliba, H. Sai, L. A. Estroff, T. Hanrath et al. Thermally induced structural evolution and performance of mesoporous block copolymer-directed alumina perovskite solar cells. Acs Nano, Vol. 8, No. 5, 2014, pp. 4730-4739.

[57] Misra, R.K., S. Aharon, B. Li, D. Mogilyansky, I. Visoly-Fisher, L. Etgar et al. Temperature-and component-dependent degradation of perovskite photovoltaic materials under concentrated sunlight. The Journal of Physical Chemistry Letters, Vol. 6, No. 3, 2015, pp. 326-330.

[58] Eperon, G. E., S.D. Stranks , C. Menelaou, M.B. Johnston, L. M. Herz and H.J. Snaith. Formamidinium lead trihalide: a broadly tunable perovskite for efficient planar heterojunction solar cells. Energy \& Environmental Science, Vol. 7, No. 3, 2014, pp. 982988.

[59] Aitdads, H., S. Bouzit, L. Nkhaili, A. Elkissani and A. Outzourhit. Structural, optical and electrical properties of planar mixed perovskite halides/Al-doped Zinc oxide solar cells. Solar Energy Materials and Solar Cells, Vol. 148, 2016, pp. 30-33.

[60] McMeekin, D. P., G. Sadoughi, W. Rehman, G. E. Eperon, M. Saliba, M. T. Horantner et al. A mixed-cation lead mixed-halide perovskite absorber for tandem solar cells. Science, Vol. 351, No. 6269, 2016, pp. 151-155.

[61] Boix, P. P., S. Agarwala, T. M. Koh, N. Mathews and S. G. Mhaisalkar. Perovskite solar cells: beyond methylammonium lead iodide. The Journal of Physical Chemistry Letters, Vol. 6, No. 5, 2015, pp. 898-907.

[62] Nie, W., J.C. Blancon, A. J. Neukirch, K. Appavoo, H. Tsai, M. Chhowalla et al. Light-activated photocurrent degradation and self-healing in perovskite solar cells. Nature Communications, Vol. 7, No. 1, 2016, pp. 1-9.

[63] Bera, A., A. D. Sheikh, M. A. Haque, R. Bose, E. Alarousu, O.F. Mohammed et al. Fast crystallization and improved stability of perovskite solar cells with $\mathrm{Zn} 2 \mathrm{SnO} 4$ electron transporting layer: interface matters. ACS Applied Materials \& Interfaces, Vol. 7, No. 51, 2015, pp. 28404-28411.

[64] Ito, S., S. Tanaka, K. Manabe and H. Nishino. Effects of surface blocking layer of $\mathrm{Sb} 2 \mathrm{~S} 3$ on nanocrystalline $\mathrm{TiO} 2$ for $\mathrm{CH} 3 \mathrm{NH} 3 \mathrm{~Pb} 33$ perovskite solar cells. The Journal of Physical Chemistry C, Vol. 118, No. 30, 2014, pp. 16995-17000.

[65] Chander, N., A. F. Khan, P. S. Chandrasekhar, E. Thouti, S. K. Swami, V. Dutta et al. Reduced ultraviolet light induced degradation and enhanced light harvesting using YVO4: Eu3+ down- 
shifting nano-phosphor layer in organometal halide perovskite solar cells. Applied Physics Letters, Vol. 105, No. 3, 2014, pp. 033904.

[66] Bailie, C. D., M. G. Christoforo, J. P. Mailoa, A. R. Bowring, E. L. Unger, W. H. Nguyen et al. Semi-transparent perovskite solar cells for tandems with silicon and CIGS. Energy \& Environmental Science, Vol. 8, No. 3, 2015, pp. 956-963.

[67] Li, Y., H. Hu, B. Chen, T. Salim, J. Zhang, J. Ding et al. Reflective perovskite solar cells for efficient tandem applications. Journal of Materials Chemistry C, Vol. 5, No. 1, 2017, pp. 134-139.

[68] Sheng, R., M. T. Hörantner, Z. Wang, Y. Jiang, W. Zhang, A. Agosti et al. Monolithic wide band gap perovskite/perovskite tandem solar cells with organic recombination layers. The Journal of Physical Chemistry C, Vol. 121, No. 49, 2017, pp. 27256-27262.

[69] Ma, Z.Q. and B. He. TCO-Si based heterojunction photovoltaic devices. In Solar Cells - Thin-Film Technologies, 4th edn, L. A. Kosyachenko, Eds, InTech, London, 2011, pp. 111-137.

[70] National Renewable Energy Laboratory (NREL). Best ResearchCell Efficiency Chart. NREL, 2019, https://www.nrel.gov/pv/ assets/pdfs/best-research-cell-efficiencies.20191105.pdf.
[71] IMEC. Perovskite/CIGS tandem cell with Record Efficiency of 24.6 percent Paves the Way for Flexible Solar Cells and High-Efficiency Building-Integrated PV. IMEC magazine, 2018, https://www.imec-int.com/en/articles/perovskite-cigstandemcell-with-record-eflciency-of-24-6-percent.

[72] Yoshikawa, K., H. Kawasaki, W. Yoshida, T. Irie, K. Konishi, K. Nakano et al. Silicon heterojunction solar cell with interdigitated back contacts for a photoconversion efficiency over $26 \%$. Nature Energy, Vol. 2, No. 5, 2017, pp. 17032.

[73] Löper, P., S.-J. Moon, S.M. De Nicolas, B. Niesen, M. Ledinsky, S. Nicolay et al. Organic-inorganic halide perovskite/crystalline silicon four-terminal tandem solar cells. Physical Chemistry Chemical Physics, Vol. 17, No. 3, 2015, pp. 1619-1629.

[74] Werner, J., F. Sahli, B. Kamino, D. Sacchetto, M. Bräuninger, A. Walter et al. Proceedings of the 44th Photovoltaic Specialist Conference (PVSC), IEEE, June 25-30, 2017, Washington, DC, 2017, pp. 3256-3259.

[75] Shockley, W. and H. J. Queisser. Detailed balance limit of efficiency of $p$-n junction solar cells. Journal of Applied Physics, Vol. 32, No. 3, 1961, pp. 510-519. 